\title{
6-Methoxyquinoline complexes as lung carcinoma agents: induction of oxidative damage on A549 monolayer and multicellular spheroid model
}

\author{
J. F. Cadavid-Vargas ${ }^{1,2} \cdot$ C. Villa-Pérez ${ }^{1} \cdot$ M. C. Ruiz ${ }^{1,2} \cdot$ I. E. León ${ }^{1} \cdot$ G. C. Valencia-Uribe ${ }^{3} \cdot$ D. B. Soria ${ }^{1}$. \\ S. B. Etcheverry ${ }^{1,2} \cdot$ A. L. Di Virgilio ${ }^{1,2}$
}

Received: 9 November 2018 / Accepted: 17 January 2019

(c) Society for Biological Inorganic Chemistry (SBIC) 2019

\begin{abstract}
The aim of this work was to study the antitumor effects and the mechanisms of toxic action of a series of 6-methoxyquinoline (6MQ) complexes in vitro. The $\mathrm{Cu}(\mathrm{II})$ and $\mathrm{Zn}$ (II) complexes (Cu6MQ and $\mathrm{Zn} 6 \mathrm{MQ}$ ) are formulated as $\mathrm{M}(6 \mathrm{MQ})_{2} \mathrm{Cl}_{2}$; the $\mathrm{Co}(\mathrm{II})$ and $\mathrm{Ag}(\mathrm{I})$ compounds (Co6MQ and Ag6MQ) are ionic with formulae $\left[\mathrm{Ag}(6 \mathrm{MQ})_{2}\right]^{+} \mathrm{NO}_{3}{ }^{-}$and $\mathrm{H}(6 \mathrm{MQ})^{+}[\mathrm{Co}(6 \mathrm{MQ})$ $\left.\mathrm{Cl}_{3}\right]^{-}$(where $\mathrm{H}(6 \mathrm{MQ})^{+}$is the protonated ligand). We found that the copper complex, outperformed the $\mathrm{Co}(\mathrm{II}), \mathrm{Zn}$ (II) and $\mathrm{Ag}(\mathrm{I})$ complexes with a lower $\mathrm{IC}_{50}(57.9 \mu \mathrm{M})$ in $\mathrm{A} 549$ cells exposed for $24 \mathrm{~h}$. Cu6MQ decreased cell proliferation and induced oxidative stress detected with $\mathrm{H}_{2}$ DCFDA at $40 \mu \mathrm{M}$, which reduces GSH/GSSG ratio. This redox imbalance induced oxidative DNA damage revealed by the Micronucleus test and the Comet assay, which turned into a cell cycle arrest at G2/M phase and induced apoptosis. In multicellular spheroids, the $\mathrm{IC}_{50}$ values tripled the monolayer model $(187.3 \mu \mathrm{M}$ for $24 \mathrm{~h})$. At this concentration, the proportion of live/dead cells diminished, and the spheroids could not proliferate or invade. Although Zn6MQ also decreased GSH/GSSG ratio from $200 \mu \mathrm{M}$ and the cytotoxicity is related to oxidative stress, the induction of the hydrogen peroxide levels only doubled the control value. Zn6MQ induced S phase arrest, which relates with the increased micronucleus frequency and with the induction of necrosis. Finally, our results reveal a synergistic activity with a 1:1 ratio of both complexes in the monolayer and multicellular spheroids.
\end{abstract}

Keywords 6-Methoxyquinoline complexes · Lung carcinoma · A549 cells · Multicellular spheroid model · Oxidative damage

Electronic supplementary material The online version of this article (https://doi.org/10.1007/s00775-019-01644-7) contains supplementary material, which is available to authorized users.

\section{A. L. Di Virgilio}

aldivirgilio@biol.unlp.edu.ar

1 CEQUINOR (CONICET-UNLP), Bv. 120 N 1465, La Plata, Argentina

2 Facultad de Ciencias Exactas, Universidad Nacional de La Plata, 47 y 115, 1900 La Plata, Argentina

3 GIAFOT, Departamento de Química, Facultad de Ciencias, Universidad Nacional de Colombia-Sede Medellín, Medellín, Colombia

\section{Introduction}

The constant worldwide expansion of a disease such as cancer is challenging the research and development of new drugs and is pushing scientists to find new and creative ways to fight against tumor development.

Oxidative damage is considered a potential therapeutic approach for the development of novel ROS-based anticancer agents. It is very well established that cancer cells display an altered metabolism with hallmarks such as an increase in the glucose uptake, increase in lactate synthesis, and an altered redox homeostasis level [1,2]. In fact, tumor cells have higher levels of endogenous reactive oxygen species (ROS) than normal cells, and this difference makes them more vulnerable to ROS-induced injury [3]. Therefore, further oxidative stress induced by exogenous agents is a strategy to selectively inhibit tumor proliferation without producing significant toxicity to normal cells 
[4]. Growing evidence suggests that increased amounts of ROS can trigger oxidative damage to lipids, proteins, and DNA. Severe permanent DNA injury leads to a mitotic catastrophe, which may then be followed by apoptosis or necrosis [5].

On the other hand, epigenetic control reversibly influences on the onset and progression of cancer [6]. This reason led to the development of new drugs that target histone deacetylases [6]. In fact, it has been reported that these enzymes may act as oncogenes since they have been found overexpressed in solid tumors and it is a point of vulnerability for cancer cells [6]. Indeed, histone deacetylases inhibition significantly alters tumor cells, inducing cell cycle arrest, differentiation, cell death, reduction of angiogenesis and also can induce an increase in the level of intracellular oxygen reactive species [7, 8]. Moreover, it has been highlighted that histone deacetylase inhibitors provoke genomic instability contributing to the cytotoxic effects of these drugs [9].

Many quinoline-based drugs that have been used in the treatment of malaria, arthritis, and lupus, showed to inhibit histone deacetylase activity $[10,11]$. In addition, it has been demonstrated that quinolines induce DNA damage and apoptosis [10] and display antiproliferative activity in in vitro and in vivo systems $[11,12]$ Significant oxidative stress induced in cells by quinolone derivatives might contribute to the antitumor effect $[13,14]$.

Previously, it has been reported the synthesis, thermal, spectral and magnetic studies of metal coordination compounds with 6-methoxyquinoline (6MQ) as ligand $[15,16]$. Moreover, the crystal structure of many complexes with 6-methoxyquinoline as ligand and transition metals have been recently reported by some of us [17]. The synthesis of these complexes has been undertaken since it is known that coordination with metals may reinforce therapeutic activity of the compounds or may allow the acquisition of beneficial actions. These complexes have shown to improve the antibacterial effect on Gram-positive and Gram-negative bacteria after complexation, although nothing is known about their activity as anticancer drugs [17].

On these bases, we are interested to evaluate if the complexation process of 6-methoxyquinoline with $\mathrm{Ag}(\mathrm{I}), \mathrm{Co}(\mathrm{II})$, $\mathrm{Cu}$ (II) and $\mathrm{Zn}$ (II) generates compounds with antitumor activity for lung carcinoma. Our study was carried out on monolayer and in a multicellular spheroid model of human lung carcinoma A549 cells, considering cell viability as a starting point to study, and the mechanisms of action involved in their antiproliferative effects. We focused our attention on the role of oxidative stress, and the cytotoxicity and genotoxicity actions of $\mathrm{Cu}(\mathrm{II})$ and $\mathrm{Zn}$ (II) complexes (Cu6MQ and $\mathrm{Zn6MQ}$ ) whose formula is $\mathrm{M}(6 \mathrm{MQ})_{2} \mathrm{Cl}_{2}$ (Fig. 1 shows the crystallographic structure) since these two resulted to be the most active and to differ from the cation effect.

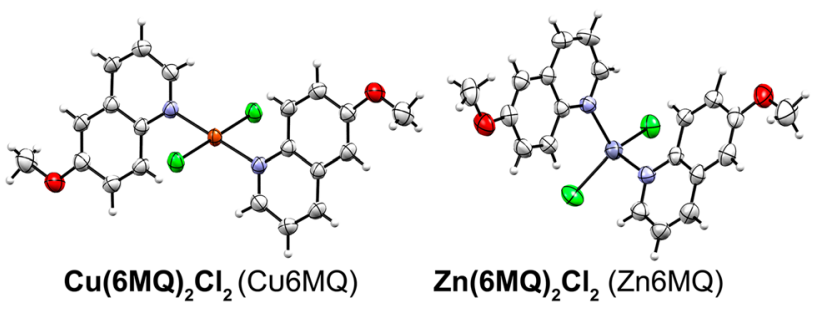

Fig. 1 ORTEP plots of Cu6MQ and Zn6MQ

\section{Materials and methods}

\section{Materials}

Tissue culture materials were purchased from Corning (Princeton, NJ, USA) and APBiotech (Buenos Aires, Argentina), Dulbecco's modified Eagle medium (DMEM), TrypLE ${ }^{\mathrm{TM}}$ from Gibco (Gaithersburg, MD, USA), and fetal bovine serum (FBS) from Internegocios SA (Buenos Aires, Argentina). 2',7'-Dichlorodihydrofluorescein diacetate $\left(\mathrm{H}_{2} \mathrm{DCFDA}\right)$ and dihydroethidium (DHE) were obtained from Molecular Probes ${ }^{\circledR}$ (Eugene, OR, USA). Annexin V, Fluorescein isothiocyanate (FITC), propidium iodide (PI) were bought from Invitrogen Corporation (Buenos Aires, Argentina). Reduced glutathione (GSH), $o$-phthalaldehyde (OPT), $n$-ethylmaleimide (NEM), vita$\min \mathrm{E}$ ( $\alpha$-tocopherol), cytochalasin and the agaroses were acquired from Sigma Aldrich (St. Louis, MO, USA). Vitamin C (ascorbic acid) from Merck (Buenos Aires, Argentina). Fluorescein diacetate and Resazurin sodium salt were purchased from Santa Cruz Biotechnology (Santa Cruz, CA, USA). A549 (CCL-185) and MRC-5 (CCL-175) cell lines were purchased from ATCC ${ }^{\circledR}$.

\section{Synthesis of transition metal complexes of 6-methoxyquinoline and aqueous stability}

Four monomeric complexes of $\mathrm{Cu}(\mathrm{II}), \mathrm{Zn}(\mathrm{II}), \mathrm{Co}(\mathrm{II})$ and $\operatorname{Ag}(\mathrm{I})$ with 6-methoxyquinoline (6MQ) as ligand have been prepared and identified according to VillaPérez et al. [17]. The $\mathrm{Cu}(\mathrm{II})$ and $\mathrm{Zn}(\mathrm{II})$ complexes are formulated as $\mathrm{Cu}(6 \mathrm{MQ})_{2} \mathrm{Cl}_{2}$ and $\mathrm{Zn}(6 \mathrm{MQ})_{2} \mathrm{Cl}_{2}$; the $\mathrm{Co}(\mathrm{II})$ and $\mathrm{Ag}(\mathrm{I})$ compounds are ionic with formulae $\left[\mathrm{Ag}(6 \mathrm{MQ})_{2}\right]^{+} \mathrm{NO}_{3}{ }^{-}$and $\mathrm{H}(6 \mathrm{MQ})^{+}\left[\mathrm{Co}(6 \mathrm{MQ}) \mathrm{Cl}_{3}\right]^{-}$(where $\mathrm{H}(6 \mathrm{MQ})^{+}$is the protonated ligand). Hereafter, the compounds will be referred as Cu6MQ, Zn6MQ, Co6MQ, and Ag6MQ, respectively.

Aqueous stability in $1000 \mu \mathrm{M}$ solutions of the complexes was measured in phosphate-buffered saline (PBS) using a Shimadzu UV-Vis spectrophotometer UV-2600 
in the range $200-400 \mathrm{~nm}$ every hour for $24 \mathrm{~h}$. To ensure the stability in biological conditions, $250 \mu \mathrm{M}$ solutions of Cu6MQ and Zn6MQ were prepared in DMEM and the spectra were recorded in the range $200-400 \mathrm{~nm}$ every hour for $24 \mathrm{~h}$ as well. The UV spectra were analyzed using the software SpectraGryph (version 1.2.7, Oberstdorf, Germany), determining the area under the curve in the whole range, followed by the evaluation of the change of area compared with the area at time 0 .

\section{Cell culture (monolayer and multicellular spheroids)}

The A549 human lung carcinoma (passages 15-35) and MRC-5 normal lung fibroblasts (passages 5-10) cell lines were cultured in DMEM supplemented with $10 \%$ FBS, 100 $\mathrm{U} / \mathrm{mL}$ penicillin, and $100 \mu \mathrm{g} / \mathrm{mL}$ streptomycin at $37^{\circ} \mathrm{C}$ in a humidified atmosphere with $5 \%$ of $\mathrm{CO}_{2}$. Cells were seeded in a T75 flask, and when $80-90 \%$ of confluence was reached, cells were subcultured using TrypLE ${ }^{\mathrm{TM}}$.

Experiments were carried out in multiwell plates, where cells were allowed to attach and were washed with DMEM before each treatment.

A549 carcinoma multicellular spheroids (MCS) were cultured using the liquid overlay method [18]. Briefly, a 96 wells plate was coated with $50 \mu \mathrm{L} 1 \%$ (w/v) sterile agarose in PBS; the gel was allowed to solidify for $20 \mathrm{~min} .10^{4}$ cells/ $\mathrm{mL}(150 \mu \mathrm{L})$ were seeded in each well and incubated at $37^{\circ} \mathrm{C}$. Half of the culture medium was replaced with complete fresh medium every other day. On the eighth day, MCS reached an average diameter between 350 and $400 \mu \mathrm{m}$ and were suitable to be treated with the complexes [19].

\section{Cell viability assay}

Monolayer cell viability was determined using 3-(4,5-dimethylthiazol-2-yl)-2,5-diphenyltetrazolium bromide (MTT), which is reduced by mitochondria in viable cells to a purple formazan dye [20]. Briefly, $2.5 \times 10^{4}$ cells were seeded on 96-well plates and incubated at $37^{\circ} \mathrm{C}$. After $24 \mathrm{~h}$, cells were exposed to different dilutions of each complex, metallic salt, and ligand for 24,48 or $72 \mathrm{~h}$. Afterward, the monolayers were washed and incubated with $0.5 \mathrm{mg} / \mathrm{mL}$ of MTT in DMEM for $3 \mathrm{~h}$. The absorbance of the formazan extracted with DMSO (100 $\mu \mathrm{L} /$ well) was recorded at a wavelength of $570 \mathrm{~nm}$ using a multiplate reader Multiskan FC (Thermo Scientific). The cell viability is shown graphically as a percent of the control value (cells treated with DMSO as vehicle).

To evaluate the role of ROS levels on cell viability, a mixture of $50 \mu \mathrm{M}$ ROS scavengers (vitamin $\mathrm{C}$ and $\mathrm{E}$ ) was simultaneously added to the culture medium with the complexes. After the incubation, the cell viability was determined by the MTT assay as previously described.
With the goal of achieving a complete outlook of the harmful effect exerted by the complexes, cell morphology was also studied. A549 cells were cultured in 6-well plates $\left(2.5 \times 10^{5}\right.$ cells/well $)$, and different concentrations of the complexes were added for $24 \mathrm{~h}$. To observe cell morphological changes, the monolayer was fixed with absolute ice-cold methanol for 5 min and stained with Giemsa (1:20 in PBS). The morphological changes were recorded using an inverted microscope Olympus BX-51 coupled to a digital camera.

\section{Clonogenic assay}

To explore if the compounds affect cell proliferation, a clonogenic assay was conducted according to [21]. $5 \times 10^{2}$ exponential growing A549 cells were plated on 6-well plates and allowed to attach overnight under standard culture conditions. The cells were washed twice with sterile PBS and treated with the complexes for $24 \mathrm{~h}$. Next, cells were washed with PBS twice and incubated with complete culture medium for 10 days. Fixation and the staining process were conducted with glutaraldehyde $6.0 \%(\mathrm{v} / \mathrm{v})$ and crystal violet $0.25 \%(\mathrm{w} / \mathrm{v})$. Colonies formed by more than 50 cells were recorded for the calculations. The surviving fraction of cells was plotted versus concentration.

\section{Oxidative stress determination}

Reduced (GSH) and oxidized (GSSG) glutathione levels were determined as described by Hissin and Hilf [22]. Confluent A549 monolayer cultured in 24-well plates were treated with different concentrations of Cu6MQ and Zn6MQ for 6 and $24 \mathrm{~h}$. Then, the monolayer was washed with PBS, and the cells were lysed with $250 \mu \mathrm{L} 0.1 \%$ Triton X-100 for $30 \mathrm{~min}$ at $4{ }^{\circ} \mathrm{C}$. For GSH determination, $100 \mu \mathrm{L}$ of the cellular lysate were added to $1.8 \mathrm{~mL}$ of ice-cold phosphate buffer $\left(\mathrm{Na}_{2} \mathrm{HPO}_{4} 0.1 \mathrm{M}\right.$ EDTA $\left.0.005 \mathrm{pH} 8.0\right)$ and $100 \mu \mathrm{L}$ $o$-phthaldialdehyde (OPT) ( $0.1 \%$ in methanol). For the determination of GSSG, $100 \mu \mathrm{L}$ of the cell lysate were mixed with $20 \mu \mathrm{L} 0.04 \mathrm{M}$ of $N$-ethylmaleimide (NEM) for $20 \mathrm{~min}$ at $4{ }^{\circ} \mathrm{C}$, then $1.8 \mathrm{~mL}$ of $\mathrm{NaOH} 0.1 \mathrm{M}$ and $100 \mu \mathrm{L}$ OPT $0.1 \%$ were added. Fluorescence was registered using a fluorometer Shimadzu RF-6000, the samples were excited at $350 \mathrm{~nm}$, and the emission signal was acquired at $420 \mathrm{~nm}$. GSH/GSSG ratio was calculated as \% of the basal for all the experimental conditions.

Transition metal complexes were tested for reactive oxygen species (ROS) induction as a mechanism of death cell by flow cytometry. $3 \times 10^{5}$ A549 cells were seeded in 12 well plates and incubated overnight. The culture medium was replaced with different concentrations of the complexes for $24 \mathrm{~h} . \mathrm{H}_{2} \mathrm{O}_{2} 0.75 \mathrm{mM}$ for $20 \mathrm{~min}$ was employed as a positive control. Then, the cellular monolayer was washed with PBS and detached with Tryple. The cells were centrifuged, 
and the pellet was incubated with DHE or $\mathrm{H}_{2}$ DCFDA $(0.8 \mu \mathrm{M})$ protected from light for $30 \mathrm{~min}$. Afterward, cells were washed twice with PBS, resuspended in $250 \mu \mathrm{l}$ PBS and transferred to flow cytometry tubes. $2 \times 10^{4}$ events were acquired in FL1 for $\mathrm{H}_{2}$ DCFDA, or FL2 for DHE using a BD FACscalibur ${ }^{\mathrm{TM}}$ flow cytometer (BD Biosciences, USA) and further analyses were performed using FlowJo 7.6 software.

\section{Apoptosis}

Cells going through different stages of apoptosis were detected with Annexin V-FITC and propidium iodide (PI) staining by measuring the externalization of phosphatidylserine (PS) and the cellular membrane integrity, respectively. Cells exposed to different concentrations of Cu6MQ and Zn6MQ for $24 \mathrm{~h}$ were detached using Tryple ${ }^{\mathrm{TM}}$ and centrifuged at 2500 RPM for 5 min. Afterward, the cellular pellet was resuspended in $100 \mu \mathrm{L}$ of binding buffer, and 2 $\mu \mathrm{L}$ of Annexin V-FITC were added, cells were incubated for $20 \mathrm{~min}$ at room temperature protected from light, and before de measurement $1 \mu \mathrm{L}$ of PI $(50 \mu \mathrm{M})$ was added. For each sample, $2 \times 10^{4}$ events were analyzed using a BD FACscalibur ${ }^{\mathrm{TM}}$ flow cytometer (BD Biosciences, USA) and further analyses were performed using FlowJo 7.6 software.

\section{Cell cycle}

DNA content in $\mathrm{G} 1 / \mathrm{G} 0, \mathrm{~S}$, and $\mathrm{G} 2 / \mathrm{M}$ phases was analyzed using flow cytometry. Cells were seeded on 6-well plates and treated with different concentrations of Cu6MQ and Zn6MQ for $24 \mathrm{~h}$. The harvested cells were washed with PBS, fixed and permeabilized with $70 \%$ ice-cold ethanol for $2 \mathrm{~h}$. Afterward, cells were suspended in $300 \mu \mathrm{L}$ staining buffer (PBS/ EDTA $2 \mathrm{mM}$, pH 8.0) and $15 \mu \mathrm{L}$ of RNAse $(1 \mathrm{mg} / \mathrm{mL})$ and incubated at $37^{\circ} \mathrm{C}$ for $15 \mathrm{~min}$. Cells were stained with PI $(15$ $\mu \mathrm{L}$ of a solution $1 \mathrm{mg} / \mathrm{mL}$ ) overnight at $8{ }^{\circ} \mathrm{C} .10^{4}$ single cells were analyzed with a BD FACscalibur ${ }^{\mathrm{TM}}$ flow cytometer; histograms depicted the relative DNA distribution within each sample. The percentage of cells in the G1/G0, S, G2/M phases and the sub-G1 peak was then calculated using the cell cycle analysis module in the FlowJo 7.6 software.

\section{Genotoxicity studies}

The cytokinesis-block micronucleus (MN) assay was set up with cultures in the log phase of growth. A549 cells were seeded onto 6-well plates and incubated at $37{ }^{\circ} \mathrm{C}$ for $24 \mathrm{~h}$. Then, the cells were treated with different concentrations of the complexes along with cytochalasin B $(4.5 \mu \mathrm{g} / \mathrm{mL})$. After $24 \mathrm{~h}$, cells were rinsed and subjected to hypotonic conditions with $0.075 \% \mathrm{KCl}$ at $37^{\circ} \mathrm{C}$ for $5 \mathrm{~min}$, fixed with pure methanol at $-20{ }^{\circ} \mathrm{C}$ for $10 \mathrm{~min}$ and stained with a $5 \%$ Giemsa solution. For the $\mathrm{MN}$ assay, 500 binucleated $(\mathrm{BN})$ cells were scored at $400 \times$ magnification per experimental point from each experiment. The examination criteria employed were reported by Fenech [23]. A pulse of $30 \mathrm{~min}$ of $0.5 \mu \mathrm{g} / \mathrm{mL}$ bleomycin was employed as the positive control.

For detection of DNA damage, the single cell gel electrophoresis assay (Comet assay) was employed based on the method of Singh et al. [23] with minor modifications. Briefly, A549 cells were treated with different concentrations of the complexes. After $24 \mathrm{~h}$, cells were suspended in $0.5 \%$ low melting point agarose and immediately poured onto microscope slides precoated with $0.5 \%$ normal melting point agarose. Two slides were prepared for each condition; one slide was used to observe single-strand DNA breaks and the other, to obtain information on the presence of oxidized DNA bases using digestion with the enzyme EndoIII [23]. Slides were immersed in ice-cold lysis solution $(2.5 \mathrm{M} \mathrm{NaCl}$, $100 \mathrm{mM}$ Na2-EDTA, $10 \mathrm{mM}$ Trizma-HCl, pH 10 and 1\% Triton $\mathrm{X}-100,10 \%$ DMSO at $4{ }^{\circ} \mathrm{C}, \mathrm{pH} 10$ ) for $1 \mathrm{~h}$ to lyse the cells, remove cellular proteins and to allow DNA unfolding. After that, the slides were washed three times ( 5 min each time) with enzyme buffer $\left(0.1 \mathrm{M} \mathrm{KCl}, 0.5 \mathrm{mM} \mathrm{Na}_{2}-\right.$ EDTA, $40 \mathrm{mM}$ HEPES-KOH, $0.2 \mathrm{mg} / \mathrm{ml} \mathrm{BSA}, \mathrm{pH} 8.0$ ) and incubated for 45 min at $37^{\circ} \mathrm{C}$ with EndoIII in the enzyme buffer or with buffer alone. Then, the slides were placed on a horizontal gel electrophoresis tank, and the DNA was allowed to unwind for $20 \mathrm{~min}$ in freshly prepared alkaline electrophoresis buffer $\left(300 \mathrm{mM} \mathrm{NaOH}\right.$ and $1 \mathrm{mM} \mathrm{Na}_{2}$-EDTA, pH 12.7). Electrophoresis was carried out in the same buffer for $30 \mathrm{~min}$ at $25 \mathrm{~V}(\approx 0.8 \mathrm{~V} / \mathrm{cm}$ across the gels and $\approx 300 \mathrm{~mA})$ in an ice bath condition. Afterward, slides were neutralized and stained with Syber Green. The analysis was performed in an Olympus BX50 fluorescence microscope. A total of 150 randomly captured cells per experimental point were used to determine the tail moment using Comet Score version 1.5 software. A pulse of $20 \mathrm{~min}$ of $10 \mu \mathrm{g} / \mathrm{mL}$ bleomycin just before the cells were harvested was employed as the positive control.

\section{Multicellular spheroids (MCS) viability assay}

The spheroid viability was assessed using the resazurin dye, which is irreversibly reduced by intracellular oxidoreductases to a pink-red fluorescent dye known as resorufin [24]. The spheroids were cultured as described and incubated with different concentrations of the complexes for 24 or $48 \mathrm{~h}$. After the exposure, the medium was replaced with $50 \mu \mathrm{M}$ resazurin solution in DMEM, and the spheroids were incubated overnight at $37^{\circ} \mathrm{C}$. Fluorescence was registered using a fluorometer Shimadzu RF-6000 (excitation at $570 \mathrm{~nm}$, emission at $585 \mathrm{~nm}$ ). Results were corrected by subtraction of the fluorescence of resazurin and DMEM alone incubated under the same conditions. Cell viability was plotted as a percentage of the basal condition (solvent control). 
Moreover, morphological changes were studied with a live-death cell staining. Multicellular spheroids treated with different concentrations of the complexes were incubated for 24 or $48 \mathrm{~h}$ and stained with fluorescein diacetate $\left(8 \times 10^{-3} \mathrm{mg} / \mathrm{mL}\right)$ and propidium iodide $\left(2 \times 10^{-2} \mathrm{mg} / \mathrm{mL}\right)$. The spheroids were incubated in the dark for $5 \mathrm{~min}$ at room temperature. The fluorescence was registered using an epifluorescence inverted microscope Nikon Ti Eclipse with FITC and Texas Red filters. The raw images were processed using Image ${ }^{\circledR}$ software, and composite RGB images were obtained.

\section{Multicellular spheroids spreading assay}

To evaluate if the cells in the spheroids can migrate and proliferate after the exposure to Cu6MQ and Zn6MQ for $24 \mathrm{~h}$, the spheroids were transferred into a 96-well plate containing $150 \mu \mathrm{L}$ of DMEM supplemented with $10 \%$ FBS and were incubated at $37{ }^{\circ} \mathrm{C}$ in a humidified atmosphere with $5 \%$ of $\mathrm{CO}_{2}$. The development of outward cellular projections from the spheroids into the well surface was registered through phase contrast microscopy after 24 and $72 \mathrm{~h}$.

\section{Synergistic calculations}

To determine the existence of a synergistic effect between Cu6MQ and Zn6MQ on A549 cells, the concentration fixed ratios $1: 1,1: 3$ and $1: 4$ of the complexes were tested. Following the same procedure applied in the cell viability assay (see "Cell viability assay"), and the data were analyzed using the Chou-Talalay method through the CompuSyn software. The results are expressed as the combination index (CI): synergistic effect $(\mathrm{CI}<1)$, additive effect $(\mathrm{CI}=1)$ and antagonism effect $(\mathrm{CI}>1)$ [5].

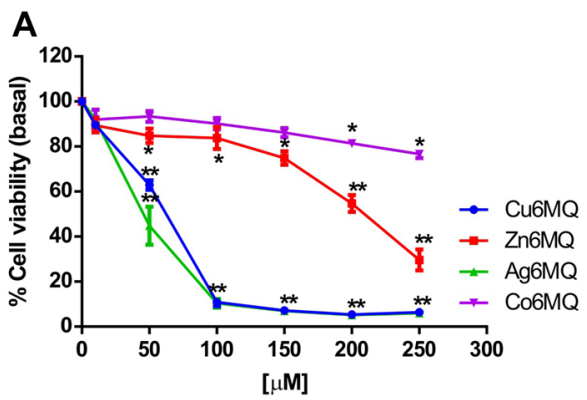

Fig. 2 a Effect of Cu6MQ, Zn6MQ, Co6MQ and Ag6MQ on A549 cell viability. Cells were incubated alone (control) or with different concentrations of the compounds at $37{ }^{\circ} \mathrm{C}$ for $24 \mathrm{~h}$. The results are expressed as the percentage of the basal level and represent the mean \pm the standard error of the mean (SEM) $(N=9)$. Asterisks represent a statistically significant difference in comparison with the basal level $*(p<0.05) * *(p<0.001)$. b Differential behavior of

\section{Statistical analysis}

Results are expressed as the mean of three independent experiments and plotted as mean \pm standard error of the mean (SEM). The total number of repeats $(n)$ is specified in the legends of the figures. The Tukey test (two way ANOVA) was employed to compare means in all the experiments performed.

\section{Results}

\section{Stability of the complexes}

The stability of the complexes was evaluated using UV-Vis spectroscopy (Fig. 1 from Supplementary Material shows the electronic absorption spectra of Cu6MQ and Zn6MQ in DMEM and Co6MQ and Ag6MQ in PBS). After $24 \mathrm{~h}$ in PBS, all the complexes kept their spectroscopic characteristics and showed a degradation rate below the $10 \%$. The stability follows: $\mathrm{Cu} 6 \mathrm{MQ}=\mathrm{Ag} 6 \mathrm{MQ}>\mathrm{Zn} 6 \mathrm{MQ}>\mathrm{Co} 6 \mathrm{MQ}$ (Fig. 2A from Supplementary Material). Moreover, in biological conditions, Cu6MQ and Zn6MQ remain stable for 24 h (Fig. 2B from Supplementary Material).

\section{Effect of 6-methoxyquinoline complexes on cell viability}

Results from the MTT assay (Fig. 2a) in A549 cell line show that Co6MQ caused no harmful effect on the tumor cells, and Ag6MQ was the most active antiproliferative compound. However, despite the remarkable effect of the silver compound, it did not show a differential cytotoxic effect when compared to the cation $\mathrm{Ag}^{+}$in the same range of concentrations (data not shown). On the other

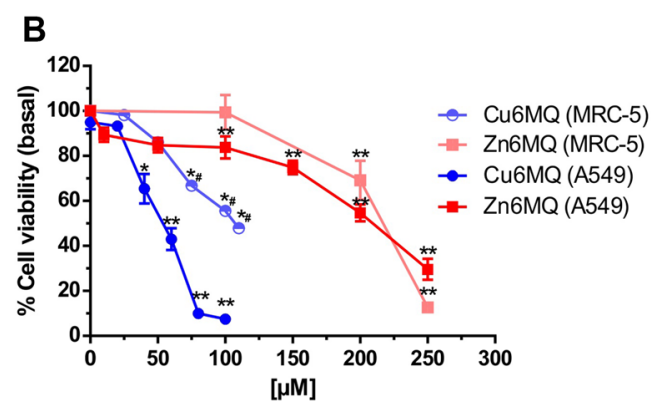

Cu6MQ and Zn6MQ on A549 and MRC-5 cell viability. The results are expressed as the percentage of the basal level and represent the mean $\pm \operatorname{SEM}(N=9)$. Asterisks represent a statistically significant difference in comparison with the basal level $*(p<0.05) * *(p<0.001)$. Number sign (\#) represents a statistically significant difference when the same complex concentration is evaluated on A549 and MRC-5 cell lines $(p<0.05)$ 
hand, Zn6MQ and Cu6MQ displayed a desirable concentration-dependent cytotoxic effect in the tumor cell line $(p<0.001)$, and a significant differential behavior when compared to the free ligand and their parent metal salts (Fig. 3 from Supplementary Material). Figure 2b shows the differential behavior between lung carcinoma and normal fibroblast for the copper and zinc complexes. Only Cu6MQ showed an acceptable difference $(p<0.05)$ with normal phenotype cells.

Half-maximal inhibitory concentrations $\left(\mathrm{IC}_{50}\right)$ also show that Cu6MQ $(57.9 \pm 5.8 \mu \mathrm{M})$ outperformed Zn6MQ $(202.3 \pm 12.2 \mu \mathrm{M})$ in inhibiting cell viability of lung carcinoma cells. Moreover, Cu6MQ induce a stronger effect than cisplatin in a $24 \mathrm{~h}$ treatment (Fig. 4 from Supplementary Material). The $\mathrm{IC}_{50}$ of cisplatin in A549 cells after $24 \mathrm{~h}$ is $266.0 \pm 40.1 \mu \mathrm{M}$.

It is worth mentioning that Cu6MQ almost totally reduced tumor cell viability at $100 \mu \mathrm{M}$ and a reduction of $70 \%$ for the $\mathrm{Zn}(\mathrm{II})$ complex-treated A549 cells was overtaken at the highest tested concentration $(250 \mu \mathrm{M})$.

On the other hand, A549 cell viability was measured as a function of time for Cu6MQ and Zn6MQ (Fig. 3). It is observed that for both compounds at each concentration, the antitumor effect is time-related.

\section{Morphological changes}

The harmful effect exerted by Cu6MQ and Zn6MQ was also confirmed by following the morphological changes on A549 cell line using Giemsa staining (Fig. 4). Lower concentrations of the complexes did not induce a significant reduction in the cell population. However, 50 and $75 \mu \mathrm{M}$ of Cu6MQ caused cytoplasmic shrinkage and moderate cell population decrease. It can be established as an indirect correlation between the presence of shrunk cells and the increase of the necrotic population in a concentration

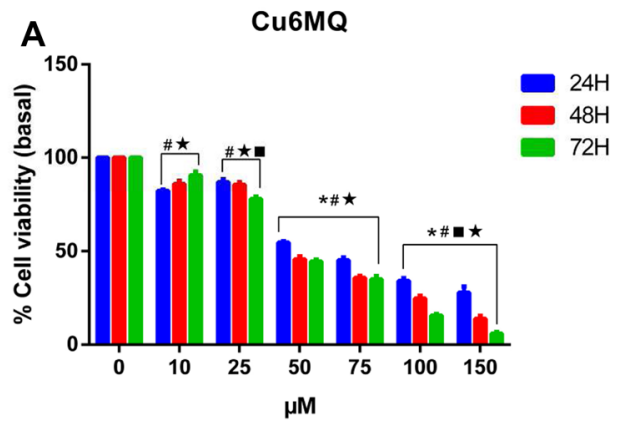

Fig. 3 Effect of Cu6MQ (A) and Zn6MQ (B) on A549 cell viability as a function of time. Cells were incubated alone (control) or with different concentrations of the compounds at $37{ }^{\circ} \mathrm{C}$ for 24,48 and $72 \mathrm{~h}$. The results are expressed as the percentage of the basal level and represent the mean \pm the standard error of the mean (SEM) $(N=9)$. $\star$ represents a statistically significant difference in com-

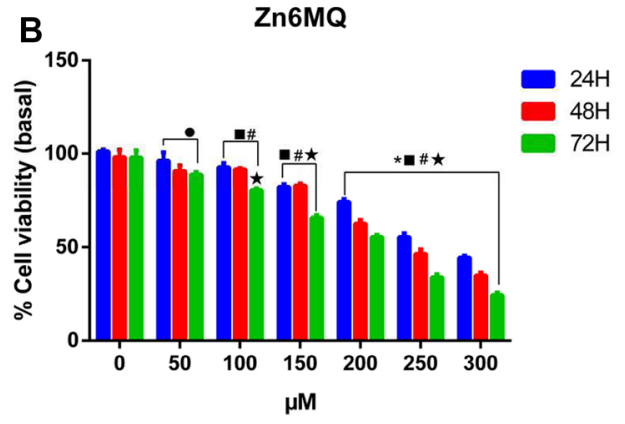

parison with the basal level $(p<0.001)$, * represents a statistically significant difference between 24 and $48 \mathrm{~h}$ treatments $p<0.001$, represents a statistically significant difference between 48 and $72 \mathrm{~h}$ treatments $p<0.001, \bullet$ represents a statistically significant difference between 24 and $72 \mathrm{~h}$ treatments $p<0.05$ and $\# p<0.001$
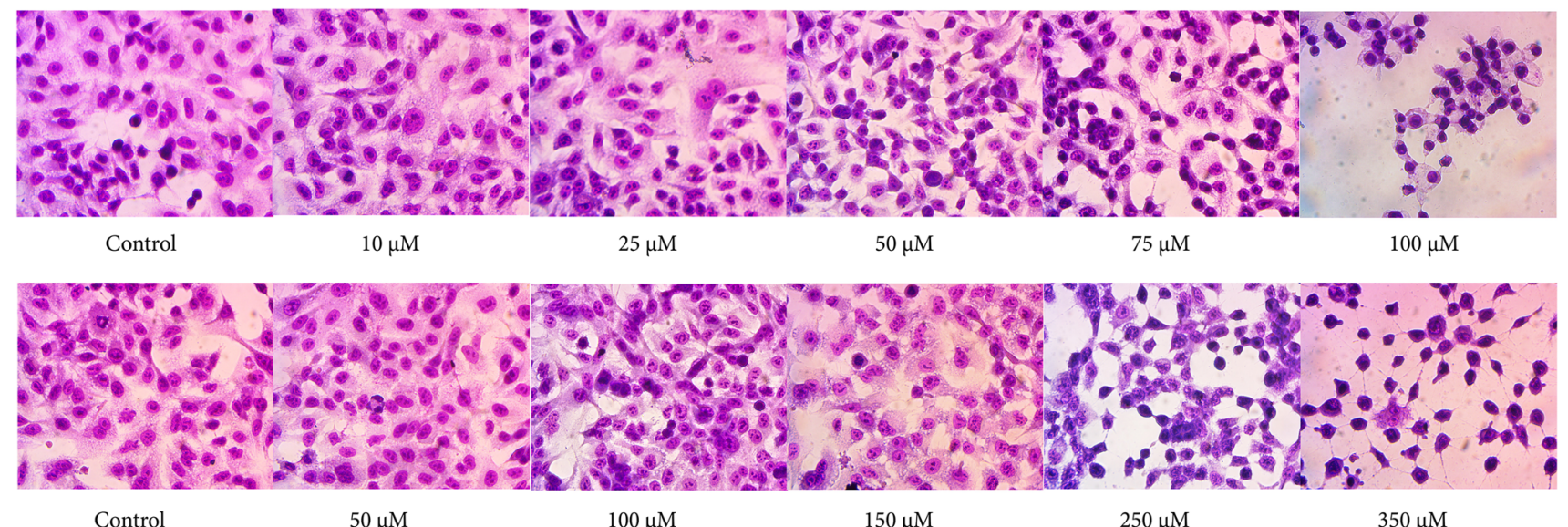

Fig. 4 Morphological changes exerted by Cu6MQ (upper panel) and Zn6MQ (bottom panel) on A549 cell line using Giemsa staining 
dependent manner. At $100 \mu \mathrm{M}$ the cell number per field was significantly reduced and presented nuclear contraction. On the other hand, Zn6MQ only induced significant changes at 250 and $350 \mu \mathrm{M}$ with remarkable population reduction with cytoplasmic and nuclear contraction.

\section{Effect on cellular proliferation}

The clonogenic assay was performed to evaluate the effect of the complexes on the cellular reproductive potential (Fig. 5) [25]. Our results showed a clear reduction of cell proliferation which agreed with the cell viability assay. Cu6MQ affected the colony formation in a dose-dependent manner (60-100 $\mu \mathrm{M}, p<0.001)$. On the other hand, Zn6MQ altered the proliferation process only in the upper range of concentrations $(250-300 \mu \mathrm{M}, p<0.001)$.

\section{Redox balance impairment}

Both, Cu6MQ and Zn6MQ decreased the GSH/GSSG ratio in a concentration-dependent way. Cu6MQ caused an equivalent disruption in the redox balance both at 6 and $24 \mathrm{~h}$ treatments, in the whole range of concentrations. In contrast, Zn6MQ modified the GSH/GSSG ratio only after $24 \mathrm{~h}$ of exposure from 200 to $400 \mu \mathrm{M}$ (Fig. $6 \mathrm{~A},{ }^{*} p<0.05$ and, $* * p<0.001$ ).

The impairment of the redox balance caused by Cu6MQ and Zn6MQ had a direct role in the cellular death process. Exogenous antioxidant scavengers $(50 \mu \mathrm{M}$ vitamin $\mathrm{C}$ and $50 \mu \mathrm{M}$ vitamin E) were added simultaneously to the complexes and a general recovery in cell viability could be observed for both complexes (Fig. 6B, $p<0.001$ ). A statistically significant difference at each concentration was found when comparing both treatments $(p<0.01)$. When vitamins were added along with the complexes, only a moderate cytotoxic effect was observed at 80 and $100 \mu \mathrm{M}$ of Cu6MQ while for Zn6MQ a similar effect was observed at 300 and $400 \mu \mathrm{M}$.

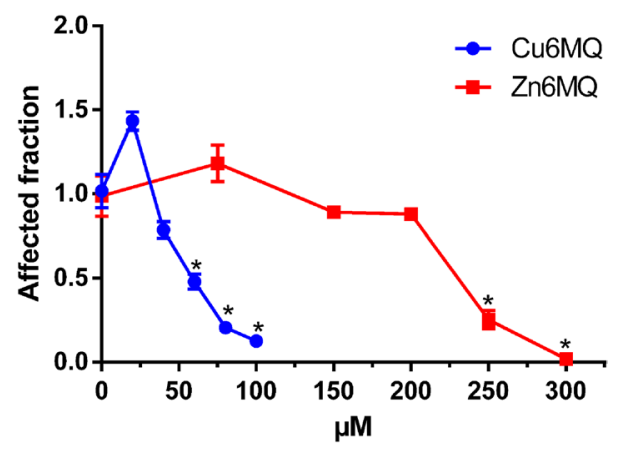

Fig. 5 Effect of Cu6MQ and Zn6MQ on A549 cell proliferation. The results represent the mean $\pm \operatorname{SEM}(N=18)$. Asterisks represent a statistically significant difference in comparison with the basal level $(p<0.001)$
As can be seen in Fig. 6C, D, Cu6MQ produced a significant increase of hydrogen peroxide detected with $\mathrm{H}_{2}$ DCFDA at $40 \mu \mathrm{M}(p<0.001)$ with a result tenfold higher than the control value, reaching the effect of positive control cells $\left(\mathrm{H}_{2} \mathrm{O}_{2}\right)$. At higher concentrations, the fluorescence intensity decreased, related to overt cytotoxicity and membrane permeability. Superoxide anion measured by the detection of DHE (Fig. 6D b) did not show a significant difference over the basal $(p>0.05)$.

Zn6MQ also induced hydrogen peroxide production from $200 \mu \mathrm{M}$, but in a less pronounced response with a result that doubled the control value (Figs. 6C, D a, $p<0.05$ ).

\section{Apoptosis induction}

Both complexes induced an apoptosis-related death at lower concentrations and turned into a necrotic effect at the higher concentrations tested (Fig. 7). Three concentrations were studied for Cu6MQ (40, 60 and $80 \mu \mathrm{M})$. At 40 and $60 \mu \mathrm{M}$, approximately $15 \%$ of the cell population was under an apoptotic process, whereas at $80 \mu \mathrm{M}$ there was a significant reduction of the apoptotic population (to $7.5 \%$ ) and an increment of the necrotic fraction to $22.1 \%(p<0.001)$. Zn6MQ-treated cells presented in the whole range of concentrations tested a high and significant $(p<0.001)$ proportion of necrotic cells, which indicates that this complex compromised the membrane integrity even at low concentrations. Moreover, the fraction of necrotic cells followed a concentration-dependent increase, i.e., 16.7, 53.3 and 76.0\% for 150,250 and $300 \mu \mathrm{M}$, respectively. Only at $150 \mu \mathrm{M}$, the apoptotic and necrotic fractions are equal.

\section{Cell cycle}

To investigate the ability of the complexes to alter cell cycle progression, the relative proportion of DNA within the cell was evaluated (Fig. 8). Cu6MQ at 50 and $100 \mu \mathrm{M}$ induced an accumulation of cells in the $\mathrm{G} 2 / \mathrm{M}$ phase, $23.2 \%$ and $21.5 \%$, respectively, $(p<0.001)$, the increase of events at this phase was at expense of the G1 population which was reduced $15 \%$ in average. The cells in $\mathrm{S}$ phase did not show any alteration in comparison with the control. On the other hand, 34\% of the cellular population was found at the $S$ phase when the cells were treated with $250 \mu \mathrm{M}$ of Zn6MQ which is a statistically significant increase $(p<0.05)$ compared with the control sample. As a consequence, the G1 cell population was reduced $17.5 \%(p<0.001)$ compared with the control group.

\section{Genotoxic effects}

A549 cells exposed to low concentrations of Cu6MQ experienced a significant increment in micronuclei formation (Fig. 9a). A concentration of $2.5 \mu \mathrm{M}$ significantly 

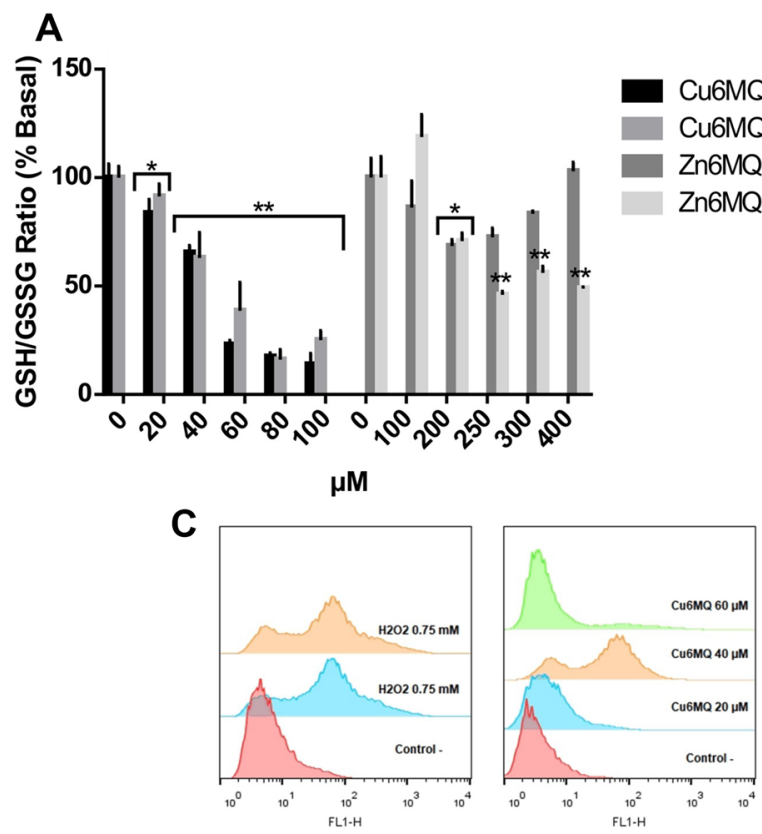

(a)

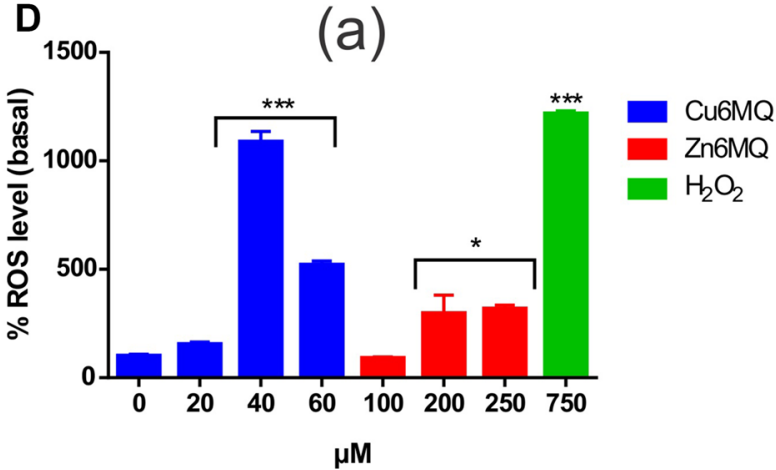

Fig. 6 A GSH/GSSG ratio after 6 or 24 h of treatment with Cu6MQ and Zn6MQ on A549 cells * and ** represent a statistically significant difference in comparison with the basal level $p<0.05$ and $p<0.001$ ), respectively. B Effect of Cu6MQ and Zn6MQ on A549 cell viability in the presence of $50 \mu \mathrm{M}$ vitamin $\mathrm{C}$ and $50 \mu \mathrm{M}$ vitamin $\mathrm{E}(p<0.001)$. Number sign (\#) represents a statistically significant difference in cell viability when general ROS scavengers are
B
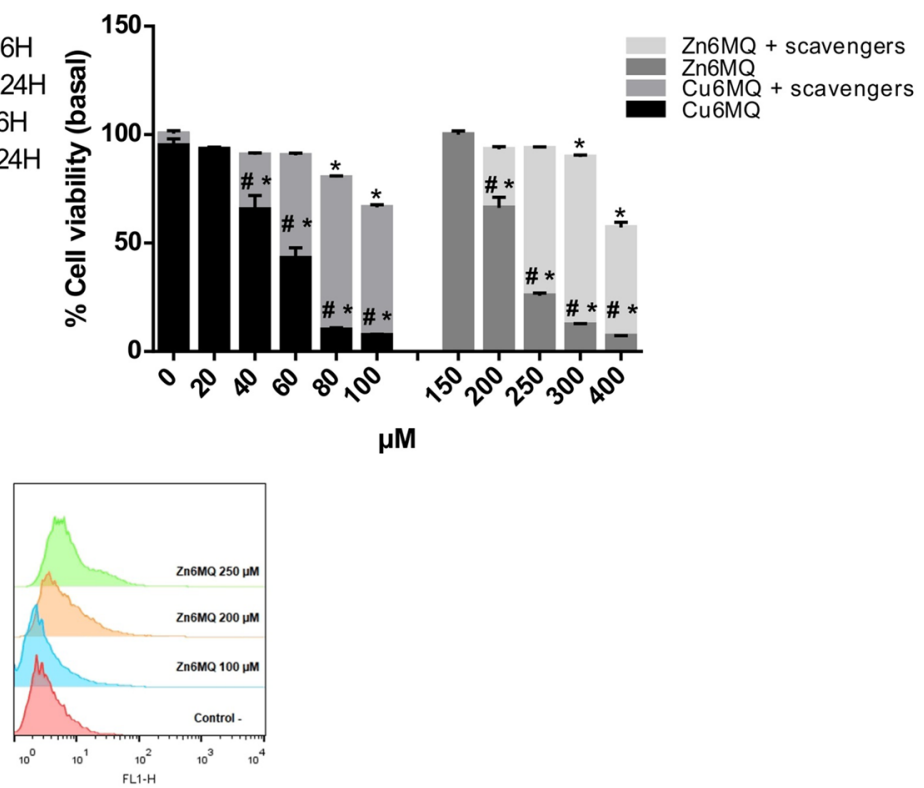

(b)

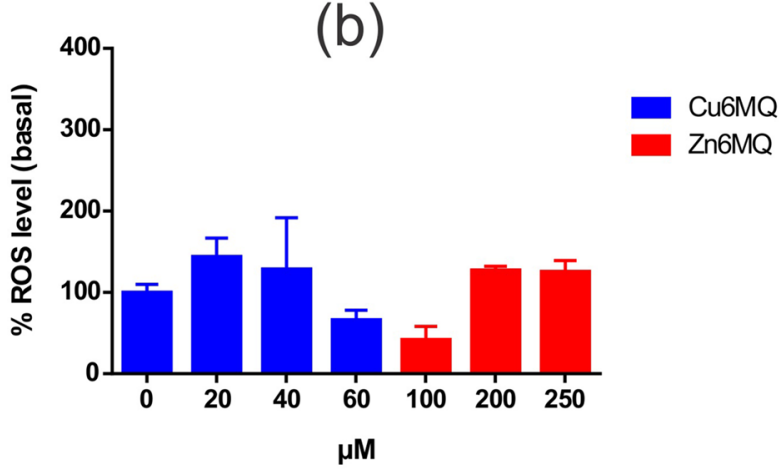

added along with the complexes $(p<0.01)$. C Flow cytometry histogram using $\mathrm{H}_{2}$ DCFDA for I and Zn6MQ on A549 cells. D Induction of ROS by Cu6MQ and Zn6MQ on A549 cells by flow cytometry a $\mathrm{H}_{2}$ DCFDA and b DHE. The results are expressed as the mean \pm SEM $(N=10)$. $*$ and $* * *$ represent a statistically significant difference in comparison with the basal level $p<0.05$ and $p<0.001$, respectively
Fig. 7 Apoptosis by flow cytometry in A549 cells treated during $24 \mathrm{~h}$ with Cu6MQ and $\mathrm{Zn6MQ}$. The results are expressed as the percentage of the basal level and represent the mean $\pm \operatorname{SEM}(N=9)$. Asterisks represent a statistically significant difference in comparison with the basal level $(p<0.001)$
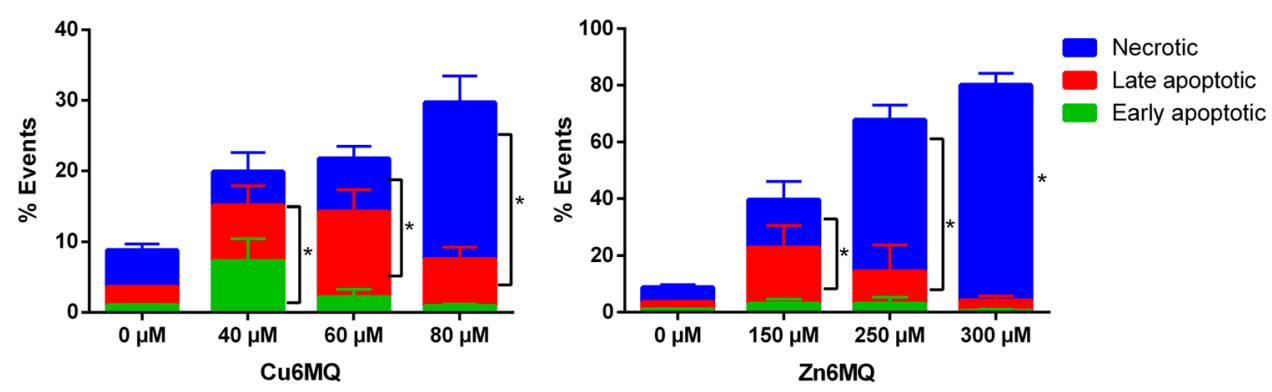

favored formation of micronuclei-which increases in a concentration-related manner-and at $25 \mu \mathrm{M}$ provoked the same effect of bleomycin $(0.7 \mu \mathrm{M})$ that we used as a positive control $(p<0.01)$. At this concentration, A549 cells experienced significant damage to DNA, which could be the origin of the micronuclei formation. A 
Fig. 8 Cell cycle arrest in A549 cells after treatment with Cu6MQ and Zn6MQ. The data are expressed as the mean $\pm \operatorname{SEM}(N=9)$. * and ** represent a statistically significant difference in comparison with the basal level $p<0.05$ and $p<0.001$, respectively
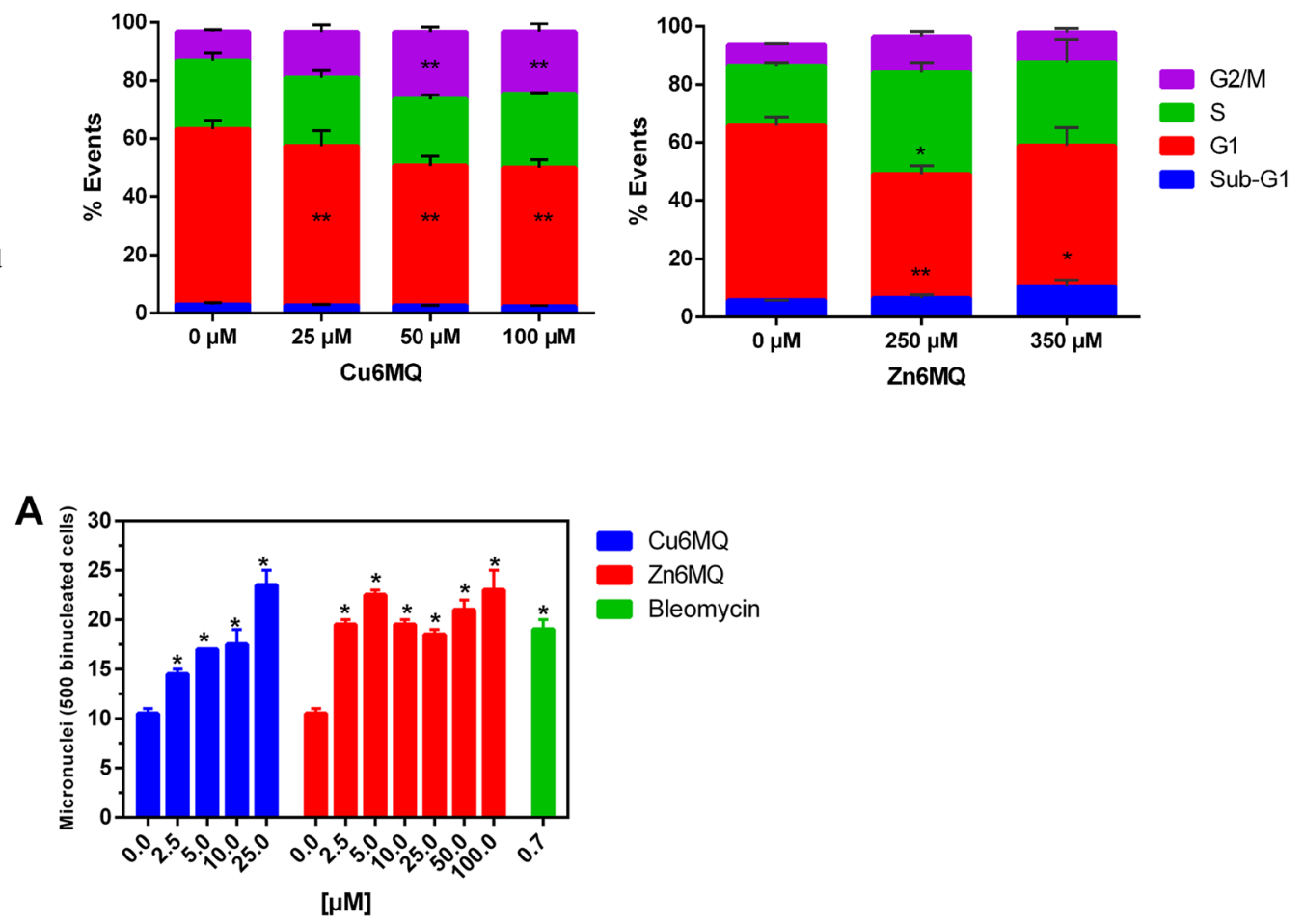

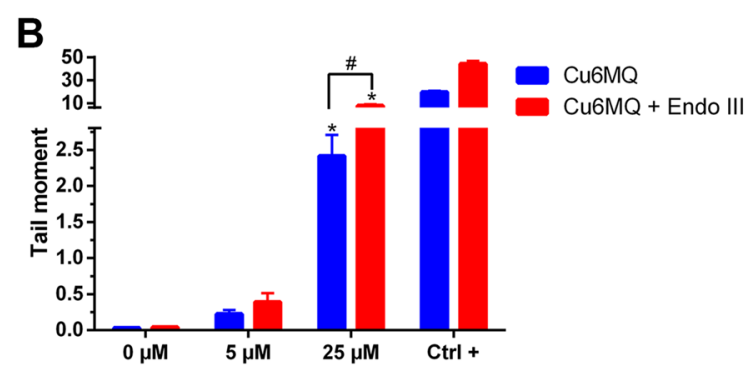

Fig. 9 a Micronucleus assay: induction of micronuclei in A549 cells after $24 \mathrm{~h}$ exposure to Cu6MQ and Zn6MQ. Asterisk represent a statistically significant difference at $p<0.01$. Bleomycin was used as a positive control. b DNA strand breaks and oxidative damage in A549 cells after $24 \mathrm{~h}$ of incubation with different concentrations of Cu6MQ

concentration of $5 \mu \mathrm{M}$ started to damage DNA but a concentration of $25 \mu \mathrm{M}$ was necessary to significantly break and liberate DNA-strands (Fig. 9b). A significant increase was observed in oxidative DNA damage detected by the employment of EndoIII, for the detection of oxidized pyrimidines $(p<0.001)$.

On the other hand, Zn6MQ-treated cells induced concentration-independent micronuclei formation in the whole concentration range with values of micronuclei per 500 binucleated cells near the positive control $(p<0.01)$. DNA damage measured by the Comet assay was also observed, but only at $50 \mu \mathrm{M}$, with the employment of EndoIII endonuclease. This enzyme releases damaged pyrimidines from double-stranded DNA and significant increase of the Tail Moment.

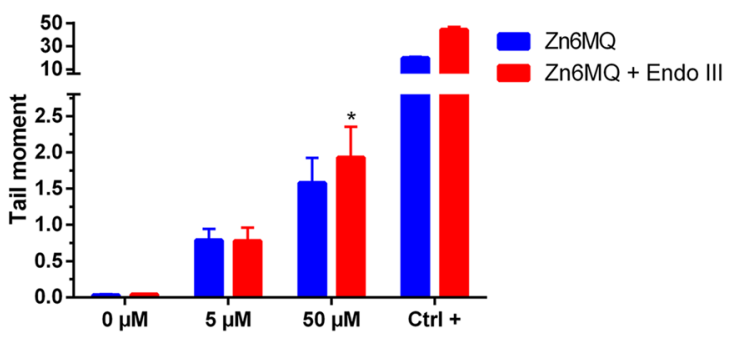

or Zn6MQ by the Comet assay. The results are expressed as the mean \pm SEM $(N=150)$. Asterisk represents a statistically significant difference at $p<0.001$. \# represents a statistically significant difference between both treatments with or without EndoIII at $p<0.001$

\section{Effect of the complexes on multicellular spheroid (MCS) cell viability}

Cell viability was screened in multicellular spheroids for both complexes at 24 and $48 \mathrm{~h}$ (Fig. 10). Cu6MQ impaired MCS viability from $100 \mu \mathrm{M}$ in a $24 \mathrm{~h}$ treatment showing a concentration-dependent manner and from $50 \mu \mathrm{M}$ when doubling the exposure time $(p<0.001)$. In this case, the MCS viability was reduced to approximately $25 \%$ in the whole range of concentrations. The $\mathrm{IC}_{50}$ values are also related to the time of exposure $(187.3 \pm 12.7 \mu \mathrm{M}$ and $7.9 \pm 3.1 \mu \mathrm{M}$ for 24 and $48 \mathrm{~h}$, respectively). In MCS exposed to Zn6MQ for $24 \mathrm{~h}$, the viability significantly decreased only at $500 \mu \mathrm{M}$, whereas, at a $48 \mathrm{~h}$ treatment, the effect begun at $300 \mu \mathrm{M}$ with a concentration-dependent 
Fig. 10 Effect of the complexes on multicellular spheroid (MCS) cell viability for 24 or $48 \mathrm{~h}$. The results are expressed as the percentage of the basal level and represent the mean $\pm \operatorname{SEM}(N=15)$. Asterisks represent a statistically significant difference in comparison with the basal level $(p<0.001)$
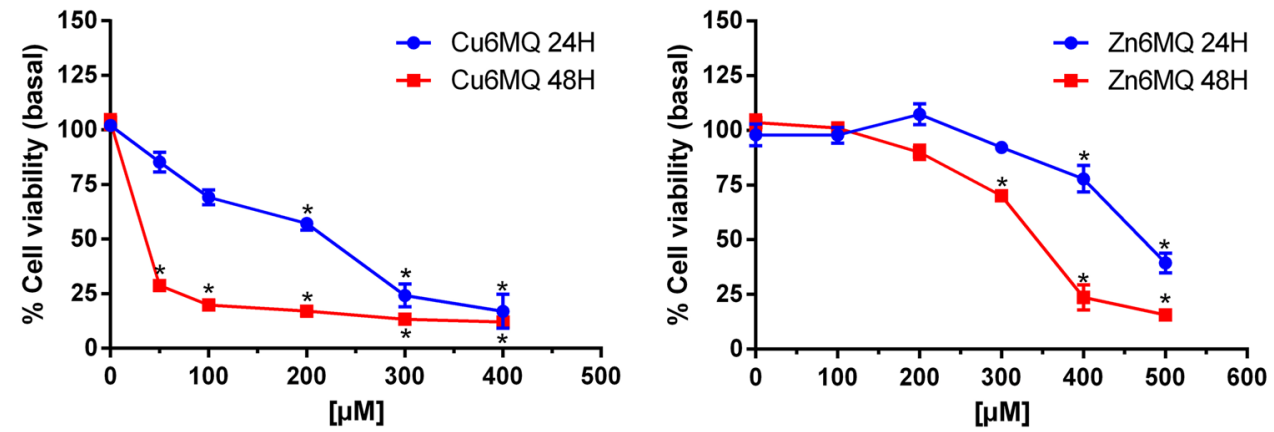

mode $\left(\mathrm{IC}_{50} 472.0 \pm 10.3 \mu \mathrm{M}\right.$ and $339.2 \pm 8.4 \mu \mathrm{M}$ for 24 and $48 \mathrm{~h}$, respectively).

Interestingly, at $24 \mathrm{~h}$ the $\mathrm{IC}_{50}$ for $\mathrm{Zn} 6 \mathrm{MQ}$ on spheroids doubled the $\mathrm{IC}_{50}$ in the $2 \mathrm{D}$ model, while for Cu6MQ the $\mathrm{IC}_{50}$ on $3 \mathrm{D}$ raised three times the $\mathrm{IC}_{50}$ found in the cellular monolayer.

Moreover, morphological changes of MCS studied with fluorescein diacetate, and propidium iodide staining agrees with the viability assay. At $24 \mathrm{~h}$ treatment, propidium iodide crosses the cell membranes in Cu6MQ-treated spheroids from $100 \mu \mathrm{M}$, denoting lack of membrane integrity within the whole spheroid. However, Zn6MQ produced a live cell staining up to $400 \mu \mathrm{M}$ and very little staining with propidium iodide in accordance with the MCS viability assay.

\section{Effect of the complexes on multicellular spheroid (MCS) spreading}

Cellular outward projections from the spheroid into the well surface were registered by phase contrast microscopy. The cells from the spheroids exposed to 10-200 $\mu \mathrm{M}$ Cu6MQ for $24 \mathrm{~h}$ could not spread in the next $24 \mathrm{~h}$ which indicates a delay in the spread and proliferation of the living cells present in the spheroid into the well surface (Fig. 11). However, after $72 \mathrm{~h}$, the spheroids showed cellular projections when exposed to Cu6MQ up to $100 \mu \mathrm{M}$. From this concentration onwards, the effect induced by the complex is irreversible and can be correlated with the lack of a layer of viable cells (green staining).

On the other hand, Zn6MQ could delay the spreading of the cells from the spheroid only after $24 \mathrm{~h}$ but not after $72 \mathrm{~h}$ of moving into the 96-well plate containing DMEM $+10 \%$ FBS. In this case, even after the exposure to high concentrations of the complex, a proliferating population outlasted and was able to spread from the spheroid to the surface.

These findings agree with the proportion of live-dead cells (superior panel in Fig. 11) since when the layer of proliferating cells diminished (and the spheroid stained in red), the spheroids could not spread into the wells with projections which happened from $100 \mu \mathrm{M}$ Cu6MQ.

\section{Synergy between Cu6MQ and Zn6MQ}

A ratio 1:1 of both complexes offers the best synergistic effect as a potential drug for cancer treatment. Our calculations of the combination index (CI) vs. affected fraction (Fa) are shown in Table 1. It summarizes the CI values of each combination at different effect levels $(0.5,0.75,0.90$ and 0.95). The results indicate that the combo Cu6MQ+Zn6MQ at a ratio $1: 1$ presented a moderate synergistic behavior with combination index (CI) varying from 0.7583 to 0.8119 . When the zinc complex proportion was increased the behavior changed into a weak additive interaction with CI values comprised between 0.9 and 1.0.

Additionally, the combo Cu6MQ+Zn6MQ (1:1) was tested on the three-dimensional model, and we found out that there is a synergistic behavior where the combination index value ranges between 0.5275 and 0.7319 . According to these results, it is observed that the synergistic effect is stronger in 3D model than in the monolayer model.

\section{Discussion}

Non-small cell lung cancer is the most common type of lung cancer and represents the main cause of cancer-associated death [26, 27]. So far, non-small cell lung tumors are poorly diagnosed in earlier stages, with bad prognosis and restricted therapeutic options. Surgery is the most recommended treatment for patients in an early-stage followed by thoracic radiotherapy and chemotherapy [28]. Current treatments involve immunotherapy and tyrosine kinase inhibitors [29]. However, the need for new antitumor treatments has been raised [30].

Nowadays, histone deacetylase inhibitors have been suggested to have a potential therapeutic role in diverse malignancies, including non-small cell lung cancer [30]. In fact, histone deacetylase inhibitors, as quinoline compounds, have been demonstrated to overcome the resistance to conventional treatments in erlotinib-resistant non-small cell lung cancer cells in vitro and in a xenograft mouse model [31], as well as in paclitaxel-resistant cells in a preclinical model 

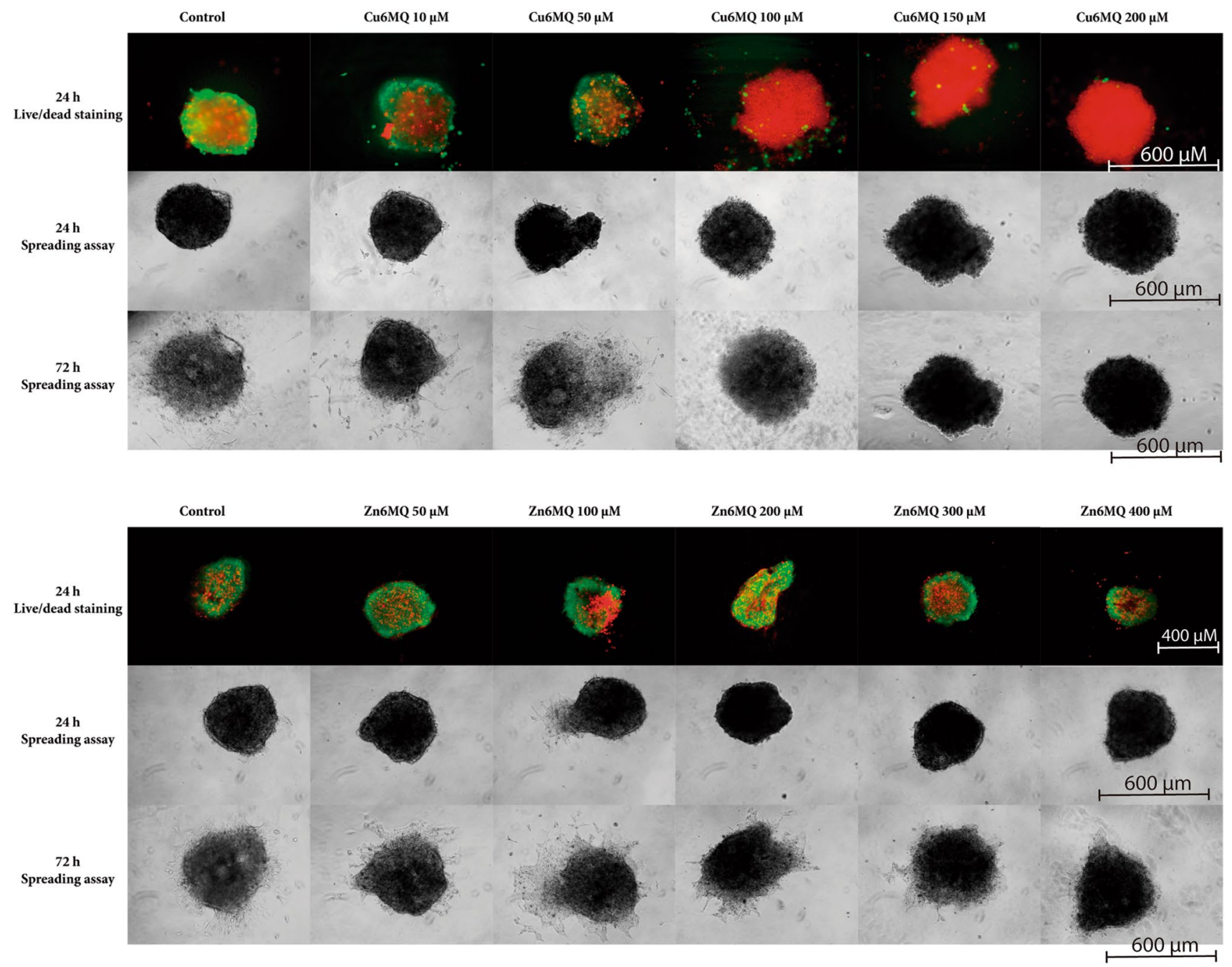

Fig. 11 Upper panel. Live-dead staining for multicellular spheroids treated with Cu6MQ or Zn6MQ for 24 h. Bottom panel. Spreading assay for spheroids treated with Cu6MQ or Zn6MQ for 24 or $72 \mathrm{~h}$

[32]. For this reason, our research was focused on the antitumor effects of metal complexes of 6-methoxyquinoline-a quinoline-based drug. The ligand by itself has no antitumor effect in epithelial carcinoma A549 cells, both in 2D and in 3D models. Besides, we have studied the mechanisms of action involved in the antitumor effects.

In the present study, a simple viability assay (MTT) was used to screen enzymatically active cells after the exposure to four metal complexes along with the ligand 6-methoxyquinoline. Since the Co complex resulted inactive and the Ag complex caused the same inhibition of tumor cell viability than the $\mathrm{Ag}^{+}$cation, we focused our attention on the $\mathrm{Cu}$ and $\mathrm{Zn}$ complexes. In accordance with the morphological features, Cu6MQ could be established as the most promising candidate since it reduces tumor cell viability affecting non-tumor cells less severely. This effect has already been studied by others. A Cu complex with a hydroxyquinoline ligand exhibited a cytostatic effect associated with an arrest of the cell cycle in the G2/M phase in different tumor cells [33]. Moreover, copper complexes with polypyridyl ligands showed remarkable activity against human-derived lung cancer cells in contrast with non-cancerous human foreskin fibroblast cells [34]. The effects of $\mathrm{Zn}$ complexes seem to be more controversial. Many $\mathrm{Zn}$ complexes demonstrated to have potential anticancer activity against different tumor cell lines. Zn(II) complexes with 2-acetylpyridine thiosemicarbazone inhibited tumor cell proliferation by arresting the cell cycle progression at the $\mathrm{S}$ phase [35]. However, a $\mathrm{Zn}$ complex with oxythiamine has been reported to be inactive against HeLa cells up to $100 \mu \mathrm{M}$ [36]. These discrepancies could be due to the difference in cell lines and time of exposure.

On the other hand, our findings further suggest that incubation of lung carcinoma cells with Cu6MQ and less 
Table 1 CI values of each combination at different effect levels $(0.5,0.75,0.90$ and 0.95$)$

\begin{tabular}{|c|c|c|c|c|c|c|}
\hline \multicolumn{7}{|l|}{ Drug combination } \\
\hline \multirow[t]{2}{*}{ Compounds } & \multicolumn{2}{|c|}{ Dose-effect parameters } & \multicolumn{4}{|l|}{$\mathrm{CI}$} \\
\hline & $\operatorname{Dm}(\mu \mathrm{M})$ & $r$ & 0.50 & 0.75 & 0.90 & 0.95 \\
\hline Cu6MQ & 52.6 & 0.955 & & & & \\
\hline Zn6MQ & 245.9 & 0.990 & & & & \\
\hline Cu6MQ:Zn6MQ (1:1) & 65.7 & 0.962 & $\begin{array}{l}0.7583 \\
++\end{array}$ & $\begin{array}{l}0.7739 \\
++\end{array}$ & $\begin{array}{l}0.7948 \\
++\end{array}$ & $\begin{array}{l}0.8119 \\
++\end{array}$ \\
\hline Cu6MQ:Zn6MQ (1:3) & 115.6 & 0.951 & $\begin{array}{l}0.9010 \\
\text { Additive }\end{array}$ & $\begin{array}{l}0.9043 \\
\text { Additive }\end{array}$ & $\begin{array}{l}0.9157 \\
\text { Additive }\end{array}$ & $\begin{array}{l}0.9284 \\
\text { Additive }\end{array}$ \\
\hline Cu6MQ:Zn6MQ (1:4) & 129.9 & 0.958 & $\begin{array}{l}0.8519 \\
\text { Additive }\end{array}$ & $\begin{array}{l}0.9484 \\
\text { Additive }\end{array}$ & $\begin{array}{l}1.0653 \\
\text { Additive }\end{array}$ & $\begin{array}{l}1.1588 \\
-\end{array}$ \\
\hline Multicellular spheroids & & & & & & \\
\hline Cu6MQ & 176.4 & 0.974 & & & & \\
\hline Zn6MQ & 469.4 & 0.991 & & & & \\
\hline Cu6MQ:Zn6MQ (1:1) & 135.3 & 0.905 & $\begin{array}{l}0.5275 \\
+++\end{array}$ & $\begin{array}{l}0.5519 \\
+++\end{array}$ & $\begin{array}{l}0.6324 \\
+++\end{array}$ & $\begin{array}{l}0.7319 \\
++\end{array}$ \\
\hline
\end{tabular}

+++ synergism, ++ moderate synergism, - moderate antagonism for Zn6MQ complexes caused a misbalance in the homeostasis of GSH, which has a vital role in cell viability. The impairment in tumor cell viability could be avoided by the exposure to ROS scavengers to prevent the imbalance in the cellular redox state (through the increase of hydrogen peroxide measured by $\mathrm{H}_{2}$ DCFDA probe). This indicates that the decrease of tumor cell viability is oxidative stressdependent. It is very well established that copper complexes increase ROS levels that cause cytotoxicity against tumor cells [37-39]. In response, cells can control the damage to a certain extent, after which vital biomolecules may be irreparably damaged. In contrast, the induction of oxidative stress is not so clear for $\mathrm{Zn}$ complexes. It is well-known that zinc(II) is not involved in redox reactions since its lack of variable valence, as is copper(II), which is prone to electron transfer. Nevertheless, $\mathrm{Zn}$ complexes have shown induction of oxidative stress in A549 cells [40] and other cancer cell lines [41].

Numerous copper coordination compounds exert their antiproliferative effect through an apoptosis type of death and cell cycle arrest $[33,42,43]$. In fact, the apoptotic fraction increased along with a $\mathrm{G} 2 / \mathrm{M}$ cell cycle arrest when cells were treated with Cu6MQ. It is also known that cells that arrest the cell cycle in G2/M due to DNA damage (provoked by an increase in oxidative stress) then can trigger apoptosis. On the other hand, cell cycle analysis showed that A549 cells accumulated in S phase in response to treatment with the $\mathrm{Zn}$ compound, which indicates that the DNA structure checkpoint fails and the cell progresses through DNA duplication in the presence of damaged DNA, eventually undergoing mitotic catastrophe (which also leads to missegregation of chromosomes and aneuploidy increasing micronucleus frequency) [44]. Finally, necrosis seems to be involved compromising the integrity of the membrane in cells cultured with the complexes.

Both compounds induced genotoxic actions against the tumor cell line. However, the copper complex caused a more pronounced and concentration-dependent effect, in agreement with the results obtained with copper and zinccontaining Schiff base complexes [45]. DNA damage can be caused by several mechanisms such as DNA intercalation, DNA oxidative cleavage or topoisomerase inhibition. Copper compounds can be responsible for all these harmful processes [46, 47]. Nevertheless, most of the studies on the mechanism of DNA damage are ROS production-related pointing to this process as the primary mechanism of action that triggers apoptosis [48]. Moreover, DNA damage can result in chromosome breaks leading to micronuclei formation (clastogenic effect). The relationship between dissolved copper and MN frequency is supported by oxidative-stress mechanisms, and more particularly by the production of reactive oxygen species, which attack DNA on the sugar residue and induce base loss and strand breaks [49].

$\mathrm{Zn}$ (II) complexes have also been demonstrated to trigger DNA damage [50]. It has been shown that $\mathrm{Zn}$ cation induces micronuclei in human leucocytes in the same range of concentrations and not in a dose-dependent manner [51]. However, the mechanisms are not so well studied. It is assumed that $\mathrm{Zn}$ interferes with DNA-repair processes in mammals via O6-alkylguanine-DNA-alkyltransferase and ligase I activities [52, 53]. Besides, it has been demonstrated that micronuclei can be induced by chemicals that are known to cause DNA replication stress and S phase arrest [54].

Multicellular spheroid (MCS) model is considered a robust model to screen the effectiveness of novel drugs in vitro. This model mimics avascular tumors and can 
display some physiological features such as nutrient, excretion products, $\mathrm{O}_{2}$ and drug gradients. Besides, cell-cell interaction is more realistic than in the monolayer model. As we expected, both compounds showed higher $\mathrm{IC}_{50}$ in the MCS model than in the monolayer cell model, with a correlation with the proportion of live-dead cells and with the inhibition of the spreading. It was previously demonstrated that the 3D cultures exhibited greater resistance to the anticancer drugs than the $2 \mathrm{D}$ cultures. This is possibly due to the morphology of the MCS, with cell-cell and cell-matrix contact, which improves the viability of the system. Another explanation can be based on the diffusion of the complexes to all the cells. Moreover, the cells on the outer layers provide a defense against exogenous agents and the hypoxic region within the spheroid is able to modulate a resistance phenomenon and thus exhibits greater viability [55]. According to our findings, several copper complexes with promising anticancer activity displayed remarkable effects against spheroids and tumor xenografts in vivo in a murine model [38] and anti-metastatic properties by inhibiting the migratory and invasive ability of cancer cells [56].

Finally, several cytotoxic drugs exhibit additive or synergistic activity without excessive toxicity, providing a promising direction for combination therapy [57]. Our results reveal that a ratio $1: 1$ of both $\mathrm{Cu}(\mathrm{II})$ and $\mathrm{Zn}$ (II) complexes in the monolayer and the 3D model offers the best synergistic effect as a novel strategy for anti-cancer therapy.

A possible synergistic effect between $\mathrm{Cu}$ and $\mathrm{Zn}$ has been proposed. It is known that copper generates oxygen species that ultimately lead to double ruptures in the DNA and that zinc harms DNA-repair enzymes in mammals potentiating the effect of $\mathrm{Cu}$ and triggering apoptosis [58].

\section{Conclusions}

Our in vitro study successfully shows that a copper complex with 6-methoxyquinoline (Cu6MQ) exerts antitumor effects in A549 cells exposed for $24 \mathrm{~h}$ and in a time-related manner through $72 \mathrm{~h}$, which occurs in parallel with an increase in ROS level. This misbalance in the redox status turns out in oxidative DNA damage and in a cell cycle arrest and apoptosis. When we move to a three-dimensional model, this effect translates into a reduction of the spreading of proliferating cells. The zinc analog shows a different mechanism of toxic action. An arrest in the $\mathrm{S}$ phase relates with the increased micronucleus frequency and with the induction of necrosis. A 1:1 concentration ratio of both complexes in the monolayer and multicellular spheroids demonstrates a synergistic effect on the impairment of cell viability. Cu6MQ resulted to be an interesting candidate for further in vivo studies.
Funding This work was supported by UNLP (11X/690, PPID 2018/ X032), CONICET (PIP 0034) and ANPCyT (PICT 2014-2223 and PICT 2016-0508) from Argentina.

\section{Compliance with ethical standards}

Conflict of interest The authors confirm that they have no conflict of interest with the content of this article.

Ethical approval This article does not contain studies with human participants or animals performed by any of the authors.

\section{References}

1. Liberti MV, Locasale JW (2016) The Warburg effect: how does it benefit cancer cells? Trends Biochem Sci 41:211-218. https:// doi.org/10.1016/j.tibs.2015.12.001

2. Li P, Zhang D, Shen L et al (2016) Redox homeostasis protects mitochondria through accelerating ROS conversion to enhance hypoxia resistance in cancer cells. Sci Rep 6:1-13. https://doi. org/10.1038/srep22831

3. Laurent A, Nicco C, Chéreau C et al (2005) Controlling tumor growth by modulating endogenous production of reactive oxygen species. Cancer Res 65:948-956

4. Lin Y, Zhang H, Liang J et al (2014) Identification and characterization of alphavirus M1 as a selective oncolytic virus targeting ZAP-defective human cancers. Proc Natl Acad Sci USA. https:// doi.org/10.1073/pnas.1408759111

5. Surova O, Zhivotovsky B (2013) Various modes of cell death induced by DNA damage. Oncogene 32:3789-3797. https://doi. org/10.1038/onc.2012.556

6. Ceccacci E, Minucci S (2016) Inhibition of histone deacetylases in cancer therapy: lessons from leukaemia. Br J Cancer 114:605611. https://doi.org/10.1038/bjc.2016.36

7. Butler LM, Zhou X, Xu W-S et al (2002) The histone deacetylase inhibitor SAHA arrests cancer cell growth, up-regulates thioredoxin-binding protein-2, and down-regulates thioredoxin. Proc Natl Acad Sci 99:11700-11705. https://doi.org/10.1073/ pnas. 182372299

8. Dawson MA, Kouzarides T (2012) Cancer epigenetics: from mechanism to therapy. Cell 150:12-27. https://doi.org/10.1016/j. cell.2012.06.013

9. Eot-Houllier G, Fulcrand G, Magnaghi-Jaulin L, Jaulin C (2009) Histone deacetylase inhibitors and genomic instability. Cancer Lett 274:169-176. https://doi.org/10.1016/j.canlet.2008.06.005

10. Martirosyan AR, Rahim-Bata R, Freeman AB et al (2004) Differentiation-inducing quinolines as experimental breast cancer agents in the MCF-7 human breast cancer cell model. Biochem Pharmacol 68:1729-1738. https://doi.org/10.1016/J.BCP.2004.05.003

11. Lee H-Y, Nepali K, Huang F-I et al (2018) ( $N$-Hydroxycarbonylbenylamino)quinolines as selective histone deacetylase 6 inhibitors suppress growth of multiple myeloma in vitro and in vivo. J Med Chem 61:905-917. https://doi.org/10.1021/acs.jmedchem.7b014 04

12. Arafa RK, Hegazy GH, Piazza GA, Abadi AH (2013) Synthesis and in vitro antiproliferative effect of novel quinoline-based potential anticancer agents. Eur J Med Chem 63:826-832. https://doi. org/10.1016/j.ejmech.2013.03.008

13. Nunoshiba T, Demple B (1993) Potent intracellular oxidative stress exerted by the carcinogen 4-nitroquinoline- $N$-oxide. Cancer Res 53:3250-3252 
14. Kwon S, Lee Y, Jung Y et al (2018) Mitochondria-targeting indolizino[3,2-c]quinolines as novel class of photosensitizers for photodynamic anticancer activity. Eur J Med Chem 148:116-127. https://doi.org/10.1016/J.EJMECH.2018.02.016

15. Allan JR, Dahyrnple J (1991) Thermal, spectral and magnetic studies of cobalt(II), copper(II) and zinc(II) complexes of 5,6-benzoquinoline and 6-methoxyquinoline. Thermochim Acta Elsevier Sci Publ BV 191:223-230

16. Villa-Pérez C, Oyarzabal I, Echeverría GA et al (2016) Singleion magnets based on mononuclear cobalt(II) complexes with sulfadiazine. Eur J Inorg Chem 2016:4835-4841. https://doi. org/10.1002/ejic.201600777

17. Villa-Pérez C, Ortega IC, Vélez-Macías A et al (2018) Crystal structure, physicochemical properties, Hirshfeld surface analysis and antibacterial activity assays of transition metal complexes of 6-methoxyquinoline. New J Chem. https://doi. org/10.1039/c8nj00661j

18. Friedrich J, Ebner R, Kunz-Schughart LA (2007) Experimental anti-tumor therapy in 3-D: spheroids-old hat or new challenge? Int J Radiat Biol 83:849-871. https://doi.org/10.1080/09553 000701727531

19. Friedrich J, Eder W, Castaneda J et al (2007) A reliable tool to determine cell viability in complex 3-D culture: the acid phosphatase assay. J Biomol Screen 12:925-937. https://doi. org/10.1177/1087057107306839

20. Mosmann T (1983) Rapid colorimetric assay for cellular growth and survival: application to proliferation and cytotoxicity assays. J Immunol Methods 65:55-63

21. Franken NAP, Rodermond HM, Stap J et al (2006) Clonogenic assay of cells in vitro. Nat Protoc 1:2315-2319. https://doi. org/10.1038/nprot.2006.339

22. Hissin PJ, Hilf R (1976) A fluorometric method for determination of oxidized and reduced glutathione in tissues. Anal Biochem 74:214-226

23. Fenech M (2000) The in vitro micronucleus technique. Mutat Res Mol Mech Mutagen 455:81-95. https://doi.org/10.1016/ S0027-5107(00)00065-8

24. Anoopkumar-Dukie S, Carey JB, Conere T et al (2005) Resazurin assay of radiation response in cultured cells. Br J Radiol 78:945-947. https://doi.org/10.1259/bjr/54004230

25. Munshi A, Hobbs M, Meyn RE (2005) Clonogenic cell survival assay. Methods Mol Med 110:21-28. https://doi.org/10.1385/159259-869-2:021

26. Jemal A, Bray F, Center MM et al (2011) Global cancer statistics. CA Cancer J Clin 61:69-90. https://doi.org/10.3322/ caac. 20107

27. Torre LA, Bray F, Siegel RL et al (2015) Global cancer statistics, 2012. CA Cancer J Clin 65:87-108. https://doi.org/10.3322/ caac. 21262

28. Hirsch FR, Scagliotti GV, Mulshine JL et al (2017) Lung cancer: current therapies and new targeted treatments. Lancet 389:299311. https://doi.org/10.1016/S0140-6736(16)30958-8

29. Novello S, Barlesi F, Califano R et al (2016) Metastatic non-smallcell lung cancer: ESMO Clinical Practice Guidelines for diagnosis, treatment and follow-up. Ann Oncol 27:V1-V27. https://doi. org/10.1093/annonc/mdw326

30. Damaskos C, Tomos I, Garmpis N et al (2018) Histone deacetylase inhibitors as a novel targeted therapy against non-small cell lung cancer: where are we now and what should we expect? Anticancer Res 38:37-43. https://doi.org/10.21873/anticanres.12189

31. Yu W, Lu W, Chen G et al (2017) Inhibition of histone deacetylases sensitizes EGF receptor-TK inhibitor-resistant non-smallcell lung cancer cells to erlotinib in vitro and in vivo. $\mathrm{Br} \mathrm{J}$ Pharmacol 174:3608-3622. https://doi.org/10.1111/bph.13961

32. Wang L, Li H, Ren Y et al (2016) Targeting HDAC with a novel inhibitor effectively reverses paclitaxel resistance in non-small cell lung cancer via multiple mechanisms. Cell Death Dis 7:e2063. https://doi.org/10.1038/cddis.2015.328

33. Rogolino D, Cavazzoni A, Gatti A et al (2017) Anti-proliferative effects of copper(II) complexes with hydroxyquinoline-thiosemicarbazone ligands. Eur J Med Chem 128:140-153. https://doi. org/10.1016/J.EJMECH.2017.01.031

34. Angel NR, Khatib RM, Jenkins J et al (2017) Copper (II) complexes possessing alkyl-substituted polypyridyl ligands: structural characterization and in vitro antitumor activity. J Inorg Biochem 166:12-25. https://doi.org/10.1016/J.JINORGBIO.2016.09.012

35. Stanojkovic TP, Kovala-Demertzi D, Primikyri A et al (2010) Zinc(II) complexes of 2-acetyl pyridine 1-(4-fluorophenyl)-piperazinyl thiosemicarbazone: synthesis, spectroscopic study and crystal structures-potential anticancer drugs. J Inorg Biochem 104:467-476. https://doi.org/10.1016/J.JINORGBIO.2009.12.021

36. Casas JS, Castellano EE, Couce MD et al (2006) Zinc(II), cadmium(II) and mercury(II) complexes of the vitamin B1 antagonist oxythiamine. J Inorg Biochem 100:124-132. https:// doi.org/10.1016/J.JINORGBIO.2005.10.009

37. Cadavid-Vargas JFJ, León IE, Etcheverry SSB et al (2017) Copper(II) complexes with saccharinate and glutamine as antitumor agents: cytoand genotoxicity in human osteosarcoma cells. Anticancer Agents Med Chem 17:424-433. https://doi. org/10.2174/1871520616666160513130204

38. Karlsson H, Fryknäs M, Strese S et al (2017) Mechanistic characterization of a copper containing thiosemicarbazone with potent antitumor activity. Oncotarget 8:30217-30234. https://doi. org/10.18632/oncotarget.16324

39. Subastri A, Suyavaran A, Preedia Babu E et al (2018) Troxerutin with copper generates oxidative stress in cancer cells: its possible chemotherapeutic mechanism against hepatocellular carcinoma. J Cell Physiol 233:1775-1790. https://doi.org/10.1002/jcp.26061

40. Martínez VR, Aguirre MV, Todaro JS et al (2018) Azilsartan and its $\mathrm{Zn}(\mathrm{II})$ complex. Synthesis, anticancer mechanisms of action and binding to bovine serum albumin. Toxicol Vitr 48:205-220. https://doi.org/10.1016/J.TIV.2018.01.009

41. Tan YS, Ooi KK, Ang KP et al (2015) Molecular mechanisms of apoptosis and cell selectivity of zinc dithiocarbamates functionalized with hydroxyethyl substituents. J Inorg Biochem 150:48-62. https://doi.org/10.1016/J.JINORGBIO.2015.06.009

42. Mohammadizadeh F, Falahati-pour SK, Rezaei A et al (2018) The cytotoxicity effects of a novel $\mathrm{Cu}$ complex on MCF-7 human breast cancerous cells. Biometals 31:233-242. https://doi. org/10.1007/s10534-018-0079-5

43. Gouda AM, El-Ghamry HA, Bawazeer TM et al (2018) Antitumor activity of pyrrolizines and their $\mathrm{Cu}(\mathrm{II})$ complexes: design, synthesis and cytotoxic screening with potential apoptosis-inducing activity. Eur J Med Chem 145:350-359. https://doi.org/10.1016/J. EJMECH.2018.01.009

44. Portugal J, Mansilla S, Bataller M (2010) Mechanisms of druginduced mitotic catastrophe in cancer cells. Curr Pharm Des 16:69-78. https://doi.org/10.2174/138161210789941801

45. Khabour OF, Saleh N, Alzoubi KH et al (2013) Genotoxicity of structurally related copper and zinc containing Schiff base complexes. Drug Chem Toxicol 36:435-442. https://doi. org/10.3109/01480545.2013.776577

46. Leon I, Cadavid-Vargas J, Di Virgilio A, Etcheverry S (2017) Vanadium, ruthenium and copper compounds: a new class of nonplatinum metallodrugs with anticancer activity. Curr Med Chem 24:112-148. https://doi.org/10.2174/09298673236661608241 62546

47. Santini C, Pellei M, Gandin V et al (2014) Advances in copper complexes as anticancer agents. Chem Rev 114:815-862. https:// doi.org/10.1021/cr400135x

48. Serment-Guerrero J, Bravo-Gomez ME, Lara-Rivera E, RuizAzuara L (2017) Genotoxic assessment of the copper chelated 
compounds Casiopeinas: clues about their mechanisms of action. J Inorg Biochem 166:68-75. https://doi.org/10.1016/J.JINOR GBIO.2016.11.007

49. Rhaese H-J, Freese E (1968) Chemical analysis of DNA alterations: I. Base liberation and backbone breakage of DNA and oligodeoxyadenylic acid induced by hydrogen peroxide and hydroxylamine. Biochim Biophys Acta Nucleic Acids Protein Synth 155:476-490. https://doi.org/10.1016/0005-2787(68)90193-7

50. Adhikari A, Kumari N, Adhikari M et al (2017) Zinc complex of tryptophan appended 1,4,7,10-tetraazacyclododecane as potential anticancer agent: synthesis and evaluation. Bioorg Med Chem 25:3483-3490. https://doi.org/10.1016/J.BMC.2017.04.035

51. Santra M, Das SK, Talukder G, Sharma A (2002) Induction of micronuclei by zinc in human leukocytes. Biol Trace Elem Res 88:139-144. https://doi.org/10.1385/BTER:88:2:139

52. Scicchitano DA, Pegg AE (1987) Inhibition of O6-alkylguanineDNA-alkyltransferase by metals. Mutat Res Lett 192:207-210. https://doi.org/10.1016/0165-7992(87)90057-1

53. Yang SW, Becker FF, Chan JYH (1996) Inhibition of human DNA ligase I activity by zinc and cadmium and the fidelity of ligation. Environ Mol Mutagen 28:19-25. https://doi.org/10.1002/ (SICI) 1098-2280(1996)28:1\%3c19:AID-EM5\%3e3.0.CO;2-9

54. Xu B, Sun Z, Liu Z et al (2011) Replication stress induces micronuclei comprising of aggregated DNA double-strand breaks. PLoS One. https://doi.org/10.1371/journal.pone.0018618
55. Galateanu B, Hudita A, Negrei C et al (2016) Impact of multicellular tumor spheroids as an in vivo-like tumor model on anticancer drug response. Int J Oncol 48:2295-2302. https://doi.org/10.3892/ ijo.2016.3467

56. Shi X, Chen Z, Wang Y et al (2018) Hypotoxic copper complexes with potent anti-metastatic and anti-angiogenic activities against cancer cells. Dalt Trans 47:5049-5054. https://doi.org/10.1039/ C8DT00794B

57. Tallarida RJ (2001) Drug synergism: its detection and applications. J Pharmacol Exp Ther 298:865-872

58. Marcato-Romain CE, Pinelli E, Pourrut B et al (2009) Assessment of the genotoxicity of $\mathrm{Cu}$ and $\mathrm{Zn}$ in raw and anaerobically digested slurry with the Vicia faba micronucleus test. Mutat Res Genet Toxicol Environ Mutagen 672:113-118. https://doi.org/10.1016/j. mrgentox.2008.10.018

Publisher's Note Springer Nature remains neutral with regard to jurisdictional claims in published maps and institutional affiliations. 